\title{
ЗАСТОСУВАННЯ РІЗНИХ ВИДІВ ТРАКЦІЙ ХРЕБЕТНОГО СТОВПА ПРИ КОМПРЕСІЙНО-КОРІНЦЕВИХ СИНДРОМАХ ПОПЕРЕКОВОГО ВІДДІЛУ ХPЕБТА
}

\author{
А. О. Голяченко, О. В. Світлак \\ Тернопільський національний медичний університет \\ імені І. Я. Горбачевського МОЗ України
}

\begin{abstract}
У статті проведено порівняльний аналіз ефективності застосування різних видів тракційної терапії у пацієнтів із компресійно-корінцевим синдромом поперекового відділу хребта. Застосування тракційних методів у комплексі зі засобами фізичної реабілітації при неускладнених компресійно-корінцевих синдромах хребта в гострий період дає можливість ефективно зменшувати больовий синдром, сприяє відновленню рухової функції хребта.
\end{abstract}

\section{APPLICATION OF DIFFERENT TYPES OF TRACTION OF THE SPINE IN RADICULAR COMPRESSION SYNDROMES OF THE LUMBAR SPINE}

\author{
A. O. Golyachenko, O. V. Svitlak
}

\section{Horbachevsky Ternopil National Medical University}

The article presents a comparative analysis of the effectiveness of different types of traction therapy in patients with radicular compression syndrome of the lumbar spine. The use of traction methods in combination with means of physical rehabilitation for uncomplicated root compression syndromes of the spine in the acute period can effectively reduce pain, helps to restore motor function of the spine.

Вступ. Хребетний стовп складається з окремих хребців, міжхребцевих дисків і розвиненого зв'язковом'язового апарату. Він утворює чотири кривизни: шийну з опуклістю вперед (шийний лордоз), грудну з опуклістю назад (грудний кіфоз), поперекову з опуклістю вперед (поперековий лордоз) і крижово-куприкову з опуклість назад на рівні 4-го крижового хребця.

3 хребта виходить 31 пара нервів. Ці нерви беруть свій початок від спинного мозку, тому їх прийнято називати спинномозковими нервами, інакше - нервові корінці, при ураженні яких формується корінцевий синдром.

Корінцевий синдром виникає досить часто і викликає сильний біль, причому не тільки в ділянці спини, але і в кінцівках, а також у ділянці внутрішніх органів, що значно ускладнює діагностування [1, 2]. Дана патологія призводить до тимчасової втрати працездатності, зумовленої больовим синдромом, спазмом м'язів та обмеженням рухів у поперековому відділі хребта $[2,3]$.

(ㄷ. А. О. Голяченко, О. В. Світлак, 2021
Основна частина. Корінцевий синдром - це неврологічний стан, зумовлений компресією одного з корінців L1-S1, для якого характерна наявність болю в попереку з іррадіацією в ногу. Компресія корінця може проявлятися не тільки болем, але і порушенням чутливості, зокрема онімінням, парестезіями або м'язовою слабкістю. Радикулопатія (корінцевий синдром) може виникати в будь-якій частині хребта, але вона найчастіше виникає в поперековому відділі. Люмбосакральну радикулопатію виявляють приблизно у 3-5 \% населення, як у чоловіків, так і жінок, але як правило, у чоловіків синдром спостерігають у віці 40 років і старше, а у жінок він розвивається у віці від 50 до 60 років [2, 3]. Лікування корінцевого синдрому попереково-крижового відділу хребта може бути проведено як за допомогою консервативних методів, так і з використанням оперативних технік [3].

Основними причинами поперекової радикулопатії $\epsilon$ :

- грижа диска або протрузія, яка може чинити тиск на нервовий корінець і призводити до запалення в ділянці корінця; 
- дегенеративне захворювання суглобів хребта, що призводить до утворення кісткових шипів на фасеточних суглобах, а в подальшому - до звуження міжхребцевого простору, що буде спричиняти компресійну дію на нервові корінці;

- травма або м'язовий спазм, що може чинити тиск на корінець і призводити до появи симптоматики в ділянці іннервації корінця;

- дегенеративне захворювання дисків, яке викликає зношування структури міжхребцевих дисків і зменшення висоти дисків, що може призвести до зменшення вільного простору в міжхребцевому отворі та компресії корінця на виході з хребетного стовпа;

- спінальний стеноз;

- пухлина;

- інфекції або системні захворювання.

Метою нашого дослідження було вивчення ефективності застосування різних видів тракційної терапії у пацієнтів із компресійно-корінцевим синдромом поперекового відділу хребта. Первинний діагноз корінцевого синдрому попереково-крижового відділу хребта встановлюють на основі симптоматики, анамнезу хвороби, даних фізичного обстеження (включаючи ретельне вивчення неврологічного статусу, мануально-м'язового тестування) та допоміжних методів обстеження (МРТ, КТ, рентгенографія хребетного стовпа). Ретельний аналіз моторної, сенсорної та рефлекторної функцій дозволяє визначити рівень ураження нервового корінця.

При виході з хребта кожен спинномозковий нерв розгалужується на нерви. Далі ці нерви йдуть в певну ділянку тіла, щоб забезпечити там іннервацію (нервову регуляцію). Ділянка тіла, яку іннервують нерви 3 одного сегмента, називається ділянкою сегментарної іннервації.

При компресійно-корінцевих синдромах виділяють декілька видів витягування: ручне витягування (проводиться мануальним терапевтом і його асистентами) - найбільш фізіологічний вид тракції з можливістю миттєвого припинення або зміни навантаження і корекції вектора прикладання сили.

При компресійно-корінцевих синдромах хребта використовують і більш тривале витягування. Хворий повинен лежати на спині, на жорсткому ліжку (під матрац підкладають дерев'яний щит), головний кінець якого піднімають на 30-35 см для витягування і утримування тіла в нахиленому положенні, при цьому верхня частина тулуба через пахвові западини фіксується за допомогою м'яких ватно-марлевих лямок, які закріплюються у головній частині ліжка.

Лікувальну фізичну культуру призначають з 3-5-го дня при загальному задовільному стані хворого, адаптації до вимушеного положення, відсутності болю в спині чи кінцівках. Лікувальна фізкультура становить основу функціонального методу лікування неускладнених компресійно-корінцевих синдромів хребта.

Останнім часом при компресійно-корінцевих синдромах поперекового відділу хребта високоефективним $\epsilon$ використання комп'ютерного витягування хребта, що дозволяє впоратися з такими недугами, як біль в поперековому, грудному і шийному відділах, компресійні та рефлекторні синдроми, спазми м'язів для зменшення внутрішньодискового тиску та патологічної імпульсації з хребетно-рухового сегмента. Даний вид тракції дозволяє дозовано здійснювати тракцію хребта та мінімізувати ризик виникнення ускладнень. Особливо показано комп'ютерне витягування хребта при грижах міжхребцевих дисків.

Метод комп'ютерного витягування хребта в комплексі зі засобами фізичної реабілітації дозволяє пацієнтам збільшити рухову активність і підвищити працездатність. Безсумнівною перевагою даного реабілітаційного комплексу з включенням витягування хребта $є$ можливість застосовувати його в будь-якому віці. Це найкраще рішення для людей, які страждають від патології хребта та міжхребцевих дисків.

Висновки. 1. Метою фізичної терапії при компресійно-корінцевих синдромах, які виникають при дегенеративно-дистрофічних ураженнях хребта, $\epsilon$ вплив на різні ланки патогенезу, зокрема дегідратувальна, протизапальна дія в ділянці компресії корінця, поліпшення колатерального кровообігу, запобігання розвитку таких ускладнень, як контрактури та деформації хребта, зменшення тяжкості тазових розладів.

2. Застосування тракційних методів у комплексі зі засобами фізіотерапії при неускладнених компресійно-корінцевих синдромах хребта в гострий період дає можливість ефективно зменшувати больовий синдром, сприяє відновленню рухової функції, знижує спастичність і нормалізує репаративну регенерацію ушкоджених тканин. 


\section{СПИСОК ЛІТЕРАТУРИ}

1. Стажадзе Л. Л. Організаційні аспекти системи травматологічної допомоги / Л. Л. Стажадзе, Е. А. Спиридонова // Медицина критических состояний. - 2018. - № 2. С. 31-35.
2. Баринов А. Н. Клініко-статистична характеристика гострої хребетно-спинномозкової травми / А. Н. Баринов, Е. Н. Кондаков // Хірургія хребта. - 2016. - № 4. - С. 15-18.

3. Цив'ян Я. Л. Пошкодження хребта / Я. Л. Цив'ян. - М. : Медицина, 2016. - 313 с.

Отримано 26.02.21 